\title{
ANALISIS PERCAKAPAN MONOLOG PADA ACARA STAND UP COMEDY METRO TV
}

\author{
Kiftian Hady Prasetya \\ Universitas Balikpapan \\ Pos-el: kiftian@uniba-bpn.ac.id
}

\begin{abstract}
ABSTRAK
Percakapan melibatkan dua orang yakni pembicara (speaker) dan pendengar (interlocutor). Bahasa humor dalam acara Stand up Comedy menyampaikan pikiran atau informasi yang berupa masalah cinta, musik, keluarga, sosial, dan lain sebagainya. Dalam humor, bahasa yang digunakan sebagai alat komunikasi melanggar maksim-maksim komunikasi. Tujuan penulisan ini untuk mendeskripsikan bagaimana percakapan dalam humor acara Stand Up Comedy dan menemukan alasan dibalik penggunaan bahasa humor yang melanggar maksim-maksim dalam sebuah percakapan. Para comic dalam acara Stand Up Comedy sering kali memendekkan kata. Sob (sobat/sahabat), gada (tidak ada), man (kawan), KW (kayak wanita) dan sebagainya. Ragam akrab yang digunakan ditandai oleh adanya hubungan akrab misalnya penggunaan bahasa yang tidak lengkap, pendek-pendek dengan artikulasi yang sedikit kurang jelas. Ragam ini digunakan untuk mengakrabkan comic sebagai pembicara dengan pemirsa setia Stand Up Comedy. Penyimpangan maksim percakapan, maksim kesopanan, dalam rangka menciptakan humor yang dilakukan lewat pemanfaatan aspek-aspek kebahasaan. Wacana humor yang diambil termasuk ke dalam wacana monolog. Dengan adanya analisis ini kita bisa melihat adanya penyimpangan dalam pemakaian bahasa, yang dapat mengecoh para penikmat atau pendengar. Sebagai penikmat dan pendengar harus senantiasa selektif dan tanggap dalam memahami sebuah topik pembicaraan sehingga maksud yang ingin disampaikan comic dapat tersampaikan dan bisa dimaknai secara keseluruhan.
\end{abstract}

Kata Kunci: percakapan, monolog, stand up comedy.

\begin{abstract}
Conversation with two speakers (speaker) and listener (interlocutor). The language of humor in the event Stand Comedy, arrange thoughts or information that contain problems of love, music, family, social, and so forth. In humor, the language used as communication medium maximcommunication. The goal is to describe how conversations in Stand Up Comedy's show humor and find the reason behind the humorous language that generates the maxims in a conversation. The comics in the Stand Up Comedy show often shorten the word, sob (buddy) gad a (no), man (friend), $K W$ (ladyboy) etc. The funny variety is characterized by aadanya privacy and it seems incomplete, short with a slightly less clear articulation.The variety in the world to familiarize the comics as a loyal speaker. The maximal deviation, the maxim of propriety, in order to create a humor that is done through the aspects of language, the humor given in the discourse monologue, with which we will be able to see the word connector in English, which can deceive the audience or listeners. As a connoisseur and listener must always be selective and responsive in understanding a topic that talks to the comic can be delivered and can be interpreted as a whole.
\end{abstract}

Keywords: conversation, monologue, stand up comedy.

Vol. 1, No. 1. Juni 2018 


\section{PENDAHULUAN}

Pada kehidupan sehari-hari kita tentu sering melakukan percakapan. Percakapan tersebut melibatkan setidaknya dua orang yakni seorang pembicara (speaker) dan seorang pendengar atau lawan bicara (interlocutor), dimana masing-masing mencoba untuk saling memahami tentang apa yang sedang dibicarakan. Orangorang yang terlibat dalam sebuah percakapan atau pembicaraan berusaha untuk memberikan informasi yang ada dalam pikirannya dan apa yang ingin diutarakan, Sedangkan peran dari seorang pendengar sendiri mencoba untuk menginterpretasian apa maksud yang terkandung dalam ujaran yang dilontarkan oleh seorang pembicara kepada pendengar.

Ketika percakapan terjadi, pembicaradan lawan bicara akan mencoba untuk memberikan informasi satu sama lain dengan tujuan apa yang mereka coba utarakan dapat di mengerti oleh keduanya sehingga maksud yang ingin diutarakan dapat disampaikan dan diterima dengan baik. Bila ditilik dari fungsi bahasa secara tradisional fungsi bahasa adalah sebagai alat komunikasi. Sebagai alat komunikasi di sini, bahasa memiliki fungsi khusus yakni menjalin hubungan solidaritas, dan kerja sama dalam masyarakat, bahasa untuk menyatakan pikiran dengan perasaan sehingga pendengar mampu merasakan apa yang akan sedang dibicarakan.

Bahasa humor stand up comedi bisa mangandung berbagai fungsi, pendapat Tarigan (1993:14) bahwa wacana suatu ucapan mungkin saja mengandung beberapa fungsi. Dari segi pendengar bahasa berfungsi direktif yaitu tingkah laku pendengar. Artinya, bahasa tidak hanya membuat pendengar melakukan sesuatu tetapi melakukan sesuai yang diminta pembicara. Jika dilihat dari segi kontak penutur dan pendengar berfungsi fatik, artinya menjalin hubungan, memelihara, memperlihatkan perasaan bersahabat atau solidaritas. Dari segi topik ujaran berfungsi denotatif atau fungsi informatif. Maksudnya sebagai alat membicarakan objek atau peristiwa yang ada di sekeliling penutur. Dari segi kode yang digunakan, bahasa berfungsi metalinguistik atau metalingual yaitu digunakan untuk membicarakan bahasa itu sendiri, misalnya membahas bahasa politik, ekonomi, pertanian dan lain sebagainya.

Dari segi amanat yang disampaikan bahasa berfungsi emaginatif. Artinya bahasa digunakan untuk menyampaikan pikiran, gagasan, dan perasaan baik yang sebenarnya, maupun imajinasi, Fungsi imaginative ini berupa lelucon dangeng cerita dan puisi). Bahasa humor yang terdapat dalam acara Stand Up Comedy selain menyampaikan pikiran atau informasi yang dikemas humor biasanya berupa masalah cinta, musi, keluarga, social, dan lain sebagainya. Dalam humur bahasa yang digunakan sebagai alat komunikasi melanggar maksim-maksim komunikasi, antara lain maksim percakapan dan kesopanan.

Penulis mencoba melihat fenomena yang terjadi dari ragam bahasa yang digunakan dalam percakapan humor Stand Up Comedy yang dilihat dari segi penutur, pemakaian, keformalan dan sarannya. Pelanggaran maksim kesopanan lazim digunakan dalam menciptakan humor. Tuturan yang dilakukan dalam acara Stand Up Comic (comic) dalam 
acara Stand Up Comedy di metro TV membentuk wacana berdasarkan tema yang telah ditentukan sebelumnya.wacana tersebut merupakan salah satu problem yang ada dalam masyarakat yang dikemas secara menarik dalam bungkusan humor dan mempunyai sifat menginformasikan sekaligus bersifat persuasif kepada pemirsa setia Stand Up Comedy untuk memberikan solusi terhadap problema tersebut.

Tujuan penulisan ini adalah untuk mendeskripsikan bagaimana percakapan dalam humor acara Stand Up Comedy. Selain itu, penulis mencoba mencari dan menemukan alasan dibalik penggunaan bahasa humor yang melanggar maksimmaksim dalam sebuah percakapan (dalam hal ini penggunaan bahasa humor) dalam acara Stand Up Comedy di Metro TV.

\section{METODE PENELITIAN}

Pendekatan yang digunakan dalam penelitian ini adalah pendekatan kualitatif. Dalam penelitian ini, data yang ditemukan dalam acara Stand Up Comedy di Metro TV pada bulan Februari tahun 2012. Data dalam penelitian ini berupa teks tulis (transkripsi teks lisan). Data dideskripsikan dan diinterpretasikan untuk mendapat jawaban yang sesuai dengan tujuan penelitian yang telah disampaikan pada bagian sebelumnya. Penulis menelaah dan mengalisis data dengan berbagai referensi yang relevan.

Penelitian ini menggunakan instrumen pengumpulan data berupa alat rekam, tabel penjaring dan analisis data serta menggunakan teknik simak dan catat yang berfokus pada wujud penyimpangan atau pelanggaran maksim dalam acara Stand Up Comedy di Metro TV.

\section{HASIL DAN PEMBAHASAN}

\section{a. Variasi Bahasa}

Chaer dan agustina (2004:62-72) menyebutkan bahwa ada beberapa variasi bahasa berdasarkan penutur, pemakai, keformalan dan sarana. Dilihat dari segi penutur, dialek para comic dalah Jakarta dialek sunda, Jakarta dialek jawa dan Jakarta dialek betawi. Misalnya comic Acho yang menggunakan bahasa Jakarta dialek betawi. Dari segi pemakian variasi Bahasa berkenaan dengan bidang penggunaan pemakaiannya dan fungsinya. Hal ini bisa dilihat dari penggunaan kosakatanya (Chaer dan agustina, 2004:68).

Pada acara Stand Up Comedy para comic menggunakan ragam bahasa yang bermacam-macam untuk keperluan humor. Misalnya ragam puisi, penggunaan bahasa dan isinya berorientasi pada kualitas estetika (Mulyana, 2005:54-55). Adapun contoh data disajikan berikut ini.

“... Saya beri gambaran. Cinta sejati adalah cinta yang memberikan sayap-sayap pada asangan anda, cinta palsu akan memberikan belenggu pada pasangan anda. Mikir! Kenapa saya berharap anda mikir, karena cinta itu ibarat ilmu sama dan erat kaitannya. Cinta dan ilmu tidak akan bermanfaat atau bermakna jika tidak dibagikan dan dipraktikan. Mikir! Karena dalam cinta juga ada ilmu 'aritmatika cinta.' Hanya saja beda aritmatika cinta, satu ditambah satu sama dengan segalanya, tapi dua dikurangi satu adalah kosong dan hampa. Maaf saya meminta anda mikir bukan tepuk tangan..." (Cak Lontong, 16 Feb 2012)

Dari wacana di atas, comic menyatakan bahwa cinta sejati adalah cinta yang memberikan kebebasan bukan memberikan belenggu. Selain itu, cinta merupakan kebersamaan antara dua orang yang saling mencintai menjadi satu. Dilihat dari segi keformalan, variasi bahasa terbagi kedalam ragam baku, 
resmi, santai dan ragam akrab. Bahasa humor Stand Up Comedy menggunakan ragam santai dan ragam akrab. Ragam santai digunakan dalam situasi yang tidak resmi bentuk allegro. Penggunaan bentuk kata atau ujaran yang dipendekkan (Chaer dan agustina, 2004:71).

Para comic dalam acara Stand $U p$ Comedy sering kali memedekkan kata misalnya, sob (sobat/sahabat, gad a (tidak ada), man (orang/kawan), KW (kayak wanita) dan lain sebagainya. Ragam akrab yang digunakan ditandai oleh aadanya hubungan akrab misalnya penggunaan bahasa yang tidak lengkap, pendek-pendek dengan artikulasi yang sedikit kurang jelas. Ragam ini digunakan untuk mengakrabkan comic sebagai pembicara dengan pemirsa setia Stand $U p$ Comedy baik yang berada di studio Metro TV maupun pemirsa yang di rumah. Dari segi saran dibedakan atas lisan dan tulisan. Ragam yang digunakan oleh para comic dalam acara Stand Up Comedy yaitu ragam lisan karena bersifat verbal yakni berupa ujaran-ujaran.

Berdasarkan pemaparan di atas comic menyajikan untaian kalimat yang berkesinambungan dari satu ide pokok ke pokok-pokok yang lain sehingga membentuk sebuah wacana yang kompleks. Hal ini terlihat dari sarana lisan bersifat verbal yang berupa ujaranujaran. Ide pokok yang mengandung problem yang bersifat persuasive. Artinya mengajak pemirsa untuk ikut menyelesaikan problem yang menjadi bahan humor. Para comic berasal dari berbagai kaum intelek. Dari segi emakaian ragam yang digunakan bermacam-macam dengan tema yang ditentukan berdasarkan segi keformalan menggunakan ragam santai dan akrab.

\section{b. Humor}

Humor merupakan satu wujd aktivitas yang tidak dapat diabaikan dalam kehidupan manusia. Humor bukan hanya bermanfaat sebagai wahana hiburan melainkan berguna untuk sarana pendidikan dan kritik social sebagai bentuk ketimpangan yang terjadi di tengah masyarakat. Jadi, humor pada hakikatnya merupakan salah satu cara untuk meningkatkan hidupnya (Wijana, 1995). Humor memliki peranan sangat sentral bagi kehidupan manusia yakni sebagai sarana hiburan dan pendidikan dalam rangka peningkatan kualitas hidup. Tidak kalah pentingnya, pada saat ini humor dimanfaatkan sebagai sarana pembangunan dan menyampaikan kritik dan saran terhadap aneka bentuk kepentingan sosial dan prolematika yang dihadapi masyarakat.

Wijana (1991:1) berpendapat bahwa, humor ditinjau dari berbagai aspek yaitu psikologis dan linguistik. Berdasarkan psikoogis humor merupakan aktivitas manusia yang muncul akibat adanya tekanan, rasa marah, sombong, dan depresi. Berdasarkan segi linguistiknya, humor merupakan penyimpangan aspekaspek pragmatik bahasa. Kaidah-kaidah dan asumsi-asumsi komunikatif yang bersifat konvensional dengan sengaja tidak dipatuhi untuk mengacaukan harapan lawan bicara atau pembaca. Tidak terwujudnya harapan inilah secara spontan potensial mengundang senyum dan tawa.

Humor terbagi menjadi humor yang bersifat positif dan negatif. Humor yang tergolong ke dalam humor negatif, yaitu humor yang isinya sesuatu yang tidak baik yakni berbau SARA (suku, agama, ras, dan antar golongan), porno, hinaan dan celaan maupun berisi sesuatu yang tidak baik. 
Humor positif yaitu humor yang bisa membangkitkan sesuatu yang baik bagi pendengarnya. Misalnya mendengar humor positif kemudian tergugah hidupnya untuk menjadi baik dan lain sebagainya. Adapula humor yang mengandung muatan sosial dan cultural yang tidak dapat dianggap enteng. Dalam sebuah percakapan banyak dijumpai penggunaan pragmati yang mengandung humor. Penulis mengatakan demikian bahwasannya dalam penggunaan bahasa humor banyak melanggar maksimmaksim yang ada. Namun banyak diantara pengguna bahasa khususna masyarakat tidak menyadari karena terjadi secara spontan tanpa disusun ataupun dirancang terlebih dahulu. Pada percakapan antara dua orang atau lebih yang terjadi secara spontan bagi seorang penutur dapat dianggap humor, namun belum tentu orang lain bergantung kepekaan serta tingkat pemahamn masing-masing orang.

Contoh tuturan:

"Terkait masalah cinta ini yang penting sekali cinta itu kalo jaman sekarang ini adalah artinya serba material. Jadi cinta adalah cincin dan permata. Jadi kalo orang jaman sekarang jatuh cinta, sayajatuh cinta karena hatinya. Hati itu artinya property. Ada juga kalo saya jatuh cinta itu berawal dari mata, mata pencahariannya..." (Setyawan, 16 Februari 2012)

Jika dilihat dari segi konteks, maksud wacana tersebut yakni cinta jaman sekarang hanya mementingkan harta semata bukan mementingkan perasaan. Maksudnya bentuk rayuan juga berkaitan dengan materi.

Pada tuturan comic Setyawan, "...Saya jatuh cinta hatinya." kata "hati" menurut comic maksudnya adalah harta dan property. Adapun pelanggaran maksim-maksim yaitu pada pelanggaran prinsip kerjasama dan kesopanan. Pertama, pelanggaran prinsip kerjasama terjadi pada maksim relevansi. Bisa dilihat dari kalimat, “...Jadi kalo orang sekarang jatuh cinta, saya jatuh cita karena hatinya. Hati artinya harta dan property." Jika mendengar orang yang merayu dan mengatakan mencintai sesorang karena hatinya pasti akan mengira bahwa dia benar-benar mencintai orang tersebut. Namun, menurut comic hati yang dimaksud adalah harta dan property.

Hal ini terlihat tidak relevan, bisa dikatakan comic sebagai penutur melanggar maksim relevansi. Kedua, Pelanggaran rinsip kesopanan terjadi pada maksim kebijaksanaan. Kalimat yang menunjukkan yakni dari kalimat "Terkait masalah cinta ini yang terpenting sekali cinta itu kalo jman sekarang ini adalah artinya material..." menurut comic cinta jaman sekarang bukan lagi tentang perasaan kasih saying tetapi lebih kepada material. Hal ini jelas merugikan orang lain yang sedang jatuh cinta. Dilihat dari data di atas bahwa comic tersebut melanggar maksim kebijaksanann.

Stand Up Comedy adalah seni humor yang disampaikan secara perorangan secara live (langsung) di depan penonton. Comic merupakan sebuah sebutan untuk penutur yang berdiri saat melakukan humor dan berbicara langsung dihadapan para penonton. Jadi tanpaada rekaan, komedianseorang diri atau individual harus membuat penonton tertawa.

Wijana (1995) menyatakan bahwa untuk mencapai proses komunikasi yang wajar, penutur dan lawan tutur harus mematuhi prinsip kerja sama pertuturan yang terjabar kedlam empat maksim percakapan, yakni maksim kuantitas, maksim kualitas, maksim relevansi dan maksim pelaksanaan. Disamping itu 
kepatuhan terhadap prinsip kerjasama, berbicara secara wajar dituntut untuk mempertimbangkan prinsip kesopanan. Dalam hal ini maksim kesopanan penutur juga tidak boleh semena-mena menggunakan tingkat kesopanan. Dalam hal ini penulis mencoba mengkaitkan parameter pragmatik yang merupakan alternative solusi dari hal tersebut agar bentuk-bentuk ujaran tidak menyinggung atau tidak janggal diucapkan.

Penulis mengambil kesimpulan bahwa penyimpangan maksim percakapan, maksim kesopanan, dalam rangka menciptakan humor yang dilakukan lewat pemanfaatan aspek-aspek kebahasaan. Wacana humor yang diambil disini termasuk ke dalam wacana monolog. Monolog merupakan kegiatan bahasa yang bersifat transisional di mana diucapkan seorang penutur. Surajat (2009:117) menyatakan bahwa molog mementingkan isi komunikasi.

Pada dasarnya monolog merupakan merupakan sebuah erkembangan tema atau gagasan dari seorang penutur. Monolog juga memiliki lebih dari satu gagasan. Penyampaiannya juga berupa lisan dan tulisan. Dalam hal ini penulis mencoba menjelaskan monolog yang berupa penyampaian lisan yaitu humor Stand Up Comedy. Di mana humor lisan pada genre ini merupakan hal menarik untuk diungkapkan mengingat sudah jarangnya humor ini dilakukan kebanyakan orang. Namun, pada jaman sekarang ini sudah mulai popular lagi.

\section{c. Ciri dan Fungsi Humor}

Dalam wacana humor maksimmaksim percakapan baik itu maksim kesopanan dan kerjasama sengaja dilanggar demi menciptakan humor. Rahmanadji (2007;213) menyatakan bahwa humor ada ketika kebutuhan naluri manusia untuk mencari, kesenangan, kegembiraan dan hiburan muncul.

Humor Stand Up Comedy dimanfaatkan sebagai sarana membawakan pesan membangun, manyampaikan kritik dan problem yang terjadi dimasyarakat yang dimana dikemas dengan balutan humor. Humor ini disajikan dalam bentuk humor tunggal yang dilakukan secara langsung di depan penonton. Pelakunya disebut comi, humor cerdas. Hal ini dituturkan oleh comic dengan latar belakang intelektual yang tinggi, di mana terdapat kreatifitas untuk mengolah tuturanya menjadi humor cerdas dengan tema yaitu problemproblem kekinian.

Sujoko (1982) menyebutkan bahwa humor memiliki fungsi untuk: 1) melaksanakan segala keinginan dan segala tujuan gagasan atau pesan, 2) menyadarkan orang bahwa dirinya tidak selalu benar, 3) mengajarkan orang melihat persoalan dari berbagai sudut, 4) menghibur, 5) melancarkan pikiran, 6) membuat orang mentoleransi sesuatu, 7) membuat orang memahami soal pelik.

\section{d. Stand Up Comedy}

Stand Up Comedy adalah cara humor tunggal yang ditayangkan oleh Metro TV. Acara ini mulai ditayangkan pada pertengahan September 2011. Pada November 2011 acara ini pindah jam tayang menjadi Rabu, pukul 22.30 dari tayangan sebelumnya yaitu Kamis, pukul 22,30. Namun, kini kembali ditayangkan pada Kamis pukul 22.30 WIB (http://id.wikipesia.org/wiki/Stand_Up_C omedy_Show).

Stand Up Comedy merupakan salah satu seni komedi yang disampaikan secara perorangan didepan public atau penonton secara langsung (live). Secara sederhana Stand Up Comedy adalah 
sebuah humor comic berbicara secara langsung di hadapan para penonton. Jadi tanpa ada rekaan, dimana seorang comic harus membuat penonton tertawa. Para pelaku humor Stand Up Comedy ini biasa disebut dengan Stand Up Comic atau Stand Up Comedian (comic).

Rosniati (2011) dalam blognya (http://ennynurr.blogspot.com/2011/10/st and-up-comedy.html) menyebutkan gaya Stand Up Comedy antara lain:

1. Observational Comedia: mengomentari sesuatu yang nyata terjadi setiap hari dan kemudian memberikan sebuah pandangan baru yang pastinya lucu. Misalnya tentang gaya pacaran atau perbedaan cewek dan cowok.

2. Political/Topical Comedian: jenis stand up ini tersulit karena politik dan religi adalah dua hal yang menjadi topik utama jenis ini.

3. Character Comedian: komedian memainkan sebuah karakter lain dari dirinya setiap kali naik panggung.

4. Props Comedian: komedian yang membawa berbagai macam barang ke atas panggung dan memberikan komentar lucu atas barang-barang itu.

5. Physical Comedian: komedian yang menggunakan tubuh sebagai "senjata"utama mereka untuk melawak.

6. Impressionist Comedian: komedian yang menirukan gaya atau suara sesuatu atau seseorang yang terkenal.

7. Improvisionalist Comedian: sebagian besar aksi komedian tipe ini diatas panggung adalah merupakan aksi atau perbuatan yang spontanitas

\section{e. Prinsip Kerjasama dan Kesopanan Grice}

Prinsip pragmatik memiliki maksim sender-sendiri diantaranya prinsip kerjasama yang terdiri atan maksim kuantitas, maksim kualitas, maksim relevansi, dan maksim pelaksanaan. Selain itu prinsip kesopanan terdiri maksim kebijaksanan, kerendahan hati, penerimaan, maksim kecocokan, kemurahan dan kesimpatian (Grice dalam Sudrajat, 2009:133-134).

\section{Prinsip Kerjasama}

Dalam rangka melaksanakan prinsip kerjasama, setiap penutur harus memenuhi empat maksim percakapan yaitu: maksim kualitas, maksim kuantitas, maksim relevansi, dan maksim pelaksanaan (Grice (dalam Wijana dan Rahmadi, 2009: 44).

Adapun pengertian dari keempat maksim tersebut:

1) Maksim Kuantitas Sudrajat (2009: 134) menyatakan maksim kuantitas menunjukkan bahwa kalimat yang diungkapkan oleh penutur harus memberikan kontribusi yang secukupnya atau sebanyak yang dibutuhkan oleh lawan tuturnya.Selain itu, pendapat lain menyatakan bahwa maksim kuantitas menghendaki setiap pertuturan memberikan kontribusi yang secukupnya atau sebanyak yang dibutuhkan oleh lawan bicaranya (Wijana dan Rohmadi, 2009: 45). Jadi pada maksim ini penutur hendaknya memberikan kontribusi yang secukupnya, sebanyak yang dibutuhkan dan tidak berlebihan dalam memberikan informasi yang diminta oleh lawan tuturnya atau dengan kata lain memberi informasi sesuai yang diminta.Adapun ciri-ciri maksim 
kuantitasmenurut Yule(2006: 64) yaitu:

a) Buatlah percakapan yang informatif seperti yang diminta (dengan maksud pergantian percakapan yang sedang berlangsung);

b) Jangan membuat percakapan lebih informatif dari yang diminta

2) Maksim Kualitas Sudrajat (2009: 134) menyatakan maksim kualitas menunjukkan bahwa kalimat yang diungkapkan oleh penuturnya berisi hal yang sebenar-benarnya. Selain itu, Wijana dan Rahmadi (2009: 47) menyatakan maksim percakapan ini mewajibkan setiap perserta percakapan hendaknya didasarkan pada bukti-bukti yang memadai. Simpulanya, maksim kualitas pada hakikatnya menunjukan kalimat yang diungkapkanya benar dan didasarkan pada bukti-bukti yang memadai. Adapun ciri-ciri maksim percakapan ini menurut Yule (2006: 64) yaitu:

(a) Cobalah untuk membuat suatu informasi yang benar;

(b) Jangan mengatakan sesuatu yang Anda yakini itu salah;

(c) Jangan mengatakan sesuatu jika Anda tidak memiliki bukti yang memadai.

3) Maksim Relevansi Sudrajat (2009: 134) menyatakan maksim relevansi menunjukkan bahwa kalimat yang diungkapkan harus relevan dengan masalah yang dibicarakan. Wijana dan Rahmadi (2009: 48) menyatakan maksim relevansi menghendaki atau mengharuskan setiap perserta percakapan memberikan kontribusi yang relevan dengan masalah pembicaraan. Jadi pada maksim ini penutur dan mitra tutur dalam membentuk percakapan yang wajar memberi sumbangan informasi yang relevan dengan masalah yang dibicarakan. Yule (2006:64), menyatakan ciri dari maksim relevansi atau hubungan ini adalah relevanlah.

4) Maksim Pelaksanaan Sudrajat (2009: 135) menyatakan maksim pelaksanaan menunjukkan bahwa kalimat yang diungkapkan oleh penutur harus langsung, tidak taksa, dan tidak berlebih. Wijana dan Rahmadi (2009) mengemukaan maksim pelaksanaan mengharuskan setiap peserta percakapan berbicara secara langsung, tidak kabur, tidak taksa, dan tidak berlebih-lebihan. Jadi pada maksim pelaksanaanperserta tutur harus terjun langsung dalam peristiwa tutur dan menghindari ketidakjelasan ungkapan, menghindari ketaksaan, mengungkapkan secara singkat, padat dan jelas (tidak belebihan). Ciri-ciri maksim ini menurut Yule (2006: 64) yaitu:

(a) Hindari ungkapan yang tidak jelas;

(b) Hindari ketaksaan;

(c) Buatlah singkat (hindarkan panjang-lebar yang tidak perlu);

(d) Buatlah secara urut/ teratur.

\section{Prinsip Kesopanan}

Wijana dan Rahmadi (2009: 47) menyatakan bahwa prinsip kesopananmemilikisejumlah maksim. Maksim-maksimyang dimaksud antara lain: maksim kebijaksanaan, maksim kemurahan, maksim penerimaan, maksim kerendahan hati, maksim kecocokan, dan maksim kesimpatian.

1. Maksim Kebijaksanaan. Maksim ini diungkapkan dengan tuturan imposifdan komisi. Maksim ini menggariskan setiap peserta 
pertuturan untuk meminimalkan kerugian orang lain, atau memaksimalkan keuntungan bagi orang lainWijana dan Rahmadi (2009: 47). Sudrajat (2009: 135) menyatakan maksim kebijaksanaan menunjukkan bahwa kalimat yang diungkapkan harus memaksimalkan keuntungan orang lain atau meminimalkan kerugian orang lain. Jadi maksim ini menggunakan tuturan komisifdan imposif. Maksudnya meminimalkan kerugian orang lain dan memaksimalkan keuntungan orang lain.

2. Maksim Penerimaa. Maksim penerimaan diutarakan dengan kalimat komisifdan imposif. Maksim ini mewajibakan setiap peserta tindak tutur untuk memaksimalkan kerugian bagi diri sendiri dan meminimalkan keuntungan bagi diri sendiri (Wijana dan Rohmadi, 2009: 55).Sudrajat (2009: 35) menyatakan bahwa maksim penerimaan menunjukkan bahwa kalimat yang diungkapkan harus memaksimalkan kerugiaan diri sendiri atau meminimalkan keuntungan diri sendiri. Jadi kalimat yang dihasilkan berupa kalimat komisi dan imposif. Maksudnya, memaksimalkan kerugian diri sendiri dan meminimalkan keuntungan diri sendiri.

3. Maksim Kemurahan Hati Wijana dan Rohmadi (2009: 56) menyatakan maksim kemurahan diutarakan dengan kalimat ekspresif dan kalimat asertif. Dengan penggunaan kalimat ekspresif dan asertif ini jelaslah bahwa tidak hanya dalam menyuruh dan menawarkan sesuatu seseorang harus berlaku sopan, tetapi di dalam mengungkapkan perasaan dan menyatakan pendapat ia tetap diwajibkan berprilaku demikian. Sudrajat (2009: 135) menyatakan bahwa maksim kemurahan hati menunjukan bahwa kalimat yang diungkapkan harus memaksimalkan rasa hormat kepada kawan bicara atau meminimalkan rasa tidak hormat kepada orang lain. Berdasarkan pernyataan-pernyataan tersebut dapat diambil simpulan bahwa, maksim kemurahan hati diutarakan dengan kalimat ekspresif dan asertif. Dengan demikian, dalam melakukan tindakan menyuruh atau menawarkan sesuatu dengan perilaku sopan karena pada prinsipnya maksim kerendahan hati mengharuskan memaksimalkan rasa hormat dan meinimalkan rasa tidak hormat kepada orang lain melalui kalimatnya.

4. Maksim Kerendahan Hati Wijana dan Rohmadi (2009: 57) menyatakan bahwa, maksim kerendahan hati diungkapkan dengan kalimat ekspresif dan asertif.Maksim kerendahan hati berpusat pada diri sendiri. Maksim kerendahan hati menuntut setiap peserta pertuturan untuk memaksimalkan ketidakhormatan pada diri sendiri dan meminimalkan rasa hormat pada diri sendiri. Sudrajat (2009: 135) menyatakan maksim kerendahan hati menunjukkan 
bahwa kalimat yang diungkapkan harus memaksimalkan ketidakhormatan pada diri sendiri atau meminimalkan rasa hormat pada diri sendiri. Jadi, maksim kerendahan hati diungkapkan dengan kalimat ekspresif dan asertif. Dengan kalimat tersebut setiap peserta tuturdituntut untuk memaksimalkan ketidakhormatan pada diri sendiri atau meminimalkan rasa hormat pada diri sendiri.

5. Maksim Kecocokan Maksim kecocokan diungkapan dengan kalimat ekspresif dan asertif. Maksim kecocokan mengariskan setiap penutur dan lawan tutur untuk memaksimalkan kecocokan di antara mereka dan meminimalkan tidak cocoknya di antara mereka (Wijana dan Rohmadi, 2009: 58). Sudrajat (2009: 135) menyatakan maksim kecocokan menunjukkan bahwa kalimat yang diungkapkan harus memaksimalkan kecocokan atau meminimalkan ketidakcocokan di antara penutur dan lawan tutur. Jadi, maksim kecocokan diungkapkan dengan kalimat ekspresif dan asertif. Maksim ini mewajibkan setiap penutur dan lawan tutur untuk memaksimalkan kecocokan dan meminimalkan ketidakcocokan diantara mereka.

6. Maksim Kesimpatian Wijana dan Rohmadi (2009: 59) menyatakan maksim kesimpatian diungkapan dengan kalimat ekspresif dan asertif. Maksim kesimpatian ini mengharuskan setiap peserta pertuturan untuk memaksimalkan rasa simpati dan meminimalkan rasa antipati kepada lawan tuturnya. Jika lawan tutur mendapatkan kesuksesan atau kebahagiaan, penutur wajib memberikan ucapan selamat.Sudrajat (2009: 136) menyatakan bahwa maksim kesimpatian menunjukkan bahwa kalimat yang diungkapkan penutur harus memaksimalkan rasa simpati atau memaksimalkan rasa antipati kepada lawan tutur. Jadi dapat disimpulkan maksim kesimpatian ini diungkapkan dengan kalimat ekspresifdan asertif. Maksim kesimpatian ini mewajibkan setiap penuturnya memaksimalkan rasa simpati atau meminimalkan rasa antipati kepada lawan tuturnya, jika lawan tutur mendapatkan kesuksesan atau kebahagiaan, penutur wajib memberikan ucapan selamat. Dari semua maksim yang terdapat pada prinsip-prinsip tersebut, dilihat pelanggaran maksim-maksim apasaja yang digunakan dalam Stand Up Comedy yang dilakukan oleh para Stand Up Comic, untuk menciptakan tuturan humornya.

\section{KESIMPULAN}

Penjelasan diatas bisa dikatakan bahwa dalam acara Stand Up Comedy dilihat dari segi percakapan monolog banyak melanggar maksim-maksim yang ada, secara sengaja demi mengaburkan maksud atau makna yang sebenarnya dengan menggunakan bungkusan humor. Dimana humor sendiri yang memiliki fungsi menghibur mengubah fungsinya menjadi sebuah kritikan yang membangun.

Penulis berusaha menjelaskan kepada khalayak penikmat humor 
bahwasannya dengan adanya analisis wacana kita bisa melihat adanya penyimpangan dalam pemakaian bahasa, yang dikemas sedemikian rupa yang dapat mengecoh para penikmat atau pendengar. Sebagai penikmat dan pendengarpun harus senantiasa selektif dan tanggap dalam memahami sebuah topik pembicaraan yang dikemas dengan sedemikian rupa menarik sehingga maksud yang ingin disampaikan comic dapat tersampaikan dan bisa dimaknai secara keseluruhan. Bisa dikatakan bahwa dengan sengaja comic mengaburkan makna sebenarnya dengan melanggar prinsip dan maksim-maksim Grice.

\section{DAFTAR PUSTAKA}

Chaer, Abdul, dan agustina, Leonie. Juni 2004. Sosiolinguistik: Perkenalan Awal. Jakarta: Rineka Cipta.

Deddy Mulyana. 2005. Ilmu Komunikasi suatu Pengantar. Bandung. PT. Remaja Rodaksa

Mulyana. 2005. Kajian Wacana. Yogyakarta: Tiara Wacana

Rosniati (2011) dalam bognya (http://ennynurr.blogspot.com/201 1/10/stand-up-comedy.html)

Sujoko.1982. Prilaku Manusia dalam Humor. Jakarta: Karya Pustaka

Tarigan.H.G. 1993. Prinsip-prinsip Dasar Sintaksi. Bandung. Aksara Bandung

Yule, George. 2006. Pragmatik. Yogyakarta: Pustaka Pelajar

Wijana, I Dewa. 1996. Dasar-dasar Pragmatik. Yogyakarta: Andi

Wijana, I Dewa Putu dan Rohmadi, M. 2009. Analisis Wacana Pragmatik. Surakarta: Yuma Pustaka http://sastra.um.ac.id/wpcontent/uploads/ 2009/10/Sejarah-Teori-Jenis-dan-FungsiHumor.pdf diakses pada tanggal $20 \mathrm{Mei}$ 2013

http://id.wikipedia.org/wiki/Stand_Up_C omedy_Show diakses tanggal 20 Mei 2013 